\title{
Communication with the Migraine Patient
}

\author{
W.J. Becker
}

\begin{abstract}
Much has been added to our knowledge of effective physician-patient communication by the research of the past two decades. Good communication skills are especially important for the clinician dealing with a migraine patient, as neither laboratory tests nor diagnostic physical findings are available to assist the physician in diagnosis and treatment. It is important for clinicians to understand that effective communication skills can be taught and learned and that, once mastered, they have the potential to improve patient outcomes.
\end{abstract}

RÉSUMÉ: La communication avec le patient migraineux. Les connaissances sur la communication efficace entre le médecin et le patient se sont développées considérablement grâce à la recherche effectuée pendant les vingt dernières années. De bonnes aptitudes à communiquer sont spécialement importantes pour le clinicien qui traite des patients migraineux parce qu'il n'existe pas de tests de laboratoire ou de signes physiques diagnostiques pour aider le médecin à établir un diagnostic et à élaborer un traitement. Il est important pour le clinicien de comprendre que les aptitudes à communiquer peuvent être enseignées et apprises et que, une fois maitrisées, peuvent améliorer les résultats pour les patients.

Can. J. Neurol. Sci. 2002; 29: Suppl. 2 - S1-S2

Much has been added to our understanding of physicianpatient communication over the past decade. Central to newer concepts of physician-patient communication is the model of a relationship-centred approach (or patient-centred approach) as opposed to other models such as a doctor-centred approach or consumerism. ${ }^{1}$ This relationship-centred care model, which emphasises meaningful two-way communication between patient and physician, is particularly appropriate for the headache patient. For success to be achieved, it is imperative for patients with difficult headache problems to be actively involved in their ongoing headache management, ${ }^{2}$ but it is also important that these patients have access to the judgment, support, knowledge and insight of a well-informed and caring physician. Successful headache management, therefore, requires physicianpatient communication at its best.

In the past, headache management has suffered badly from poor physician-patient communication and this may have contributed to the finding that many patients become "lapsed consulters", even though their headache management remains suboptimal. ${ }^{3,4}$ In addition, many patients with migraine who continue to see physicians are not accurately diagnosed, 5,6 and even those who are diagnosed with migraine are often undertreated., ${ }^{7,8}$

It is puzzling why many physicians should treat patients with difficult migraine problems with medications effective only for patients with much milder headaches. Cost may be an issue, as many of the newer more effective symptomatic migraine medications, e.g. the triptans, are much more expensive than older medications such as the analgesics. It would also appear, however, that many physicians do not appreciate how much disability many of their migraine patients are experiencing as a result of their headaches.

The workshop on which this supplement is based, "Migraine: The Doctor-Patient Link", was organised to address some of these issues. It was held in Toronto on February 24, 2001. It focused on bringing neurologists up-to-date in terms of what is known about effective physician/patient communication, and on using communication techniques including standardised migraine disability and quality of life instruments, to more effectively assess migraine-related disability. There was also emphasis on using good communication skills to more effectively diagnose and treat the patient with migraine. Although some primary care physicians with a major interest in migraine were also present at the workshop, it was also hoped that those present would disseminate their knowledge further among primary care physicians in Canada.

The workshop was held under the auspices of the Canadian Headache Society and was financially sponsored by an unrestricted educational grant by Glaxo SmithKline Inc. It

From the University of Calgary and Calgary Regional Health Authority, Calgary, Alberta Canada.

Reprint requests to: W J Becker, Foothills Hospital, 12th Floor, Neurology, 1403 29th Street NW, Calgary, Alberta Canada T2N 2T9 
consisted of individual lectures focusing on the use of effective communication in making the diagnosis and in presenting treatment options to the patient. There was also a special focus on the assessment of migraine-related disability and quality of life. Finally, participants took part in small group sessions, which were focused on a video portraying a physician interview with a patient with migraine. The emphasis in the small group sessions was on communication, and on what was effective and what was not, rather than on the medical content of the patient interview. The small group participants then reassembled in a plenary session to review their conclusions from the small group session.

A central feature of the workshop was a presentation by a nonphysician educator, Dr Suzanne Kurtz, who has actively taught and published in the medical communication field for many years. Her presentation, which is also summarised in this supplement, emphasised that good communication techniques can be systematically analysed and understood, and that skillful use of these can be taught and learned. Physicians who believe that excellent communication skills are an innate part of personality and are something that one must be born with are woefully out of date. In addition, it is clear that there is probably room for even the best of us to improve our communication skills further and that doing so will make us more effective physicians in every medical sense. In other words, improving our communication skills is one way of improving our patient outcomes.

Recent medical graduates have often had the benefit of relatively comprehensive courses in medical communication. The same is not true of many more experienced physicians. As Dr Kurtz points out, when it comes to communication, experience is not always the best teacher. For physicians working with headache patients, there seems little doubt that any time spent in improving communication skills will be a good investment. One of the goals of this supplement is to make physicians who work with patients with headache more aware of this, and to help them on the journey to better physician-patient communication.

\section{REFERENCES}

1. Silverman J, Kurtz S, Draper J. Skills for communicating with patients. Radcliffe Medical Press, Abingdon UK, 1998

2. Pryse-Phillips WEM. The role of the patient in maximising efficacy of drug therapy in migraine. Dis Manage Health Outcomes 2001;9:187-201

3. Edmeads $\mathbf{J}$, Findlay $\mathrm{H}$, Tugwell $\mathrm{P}$, et al. Impact of migraine and tension-type headache on lifestyle, consulting behaviour and medication use: a Canadian population study. Can J Neurol Sci 1993;20:131-137.

4. Pryse-Phillips WEM, Findlay $\mathrm{H}$, Tugwell $\mathrm{P}$, et al. A Canadian population study on clinical, epidemiologic and societal impact of migraine and tension-type headache. Can J Neurol Sci 1992;19:333-339.

5. Lipton RB, Stewart WF, Simon D. Medical consultation for migraine: the results from the American Migraine Study. Headache 1998;38:87-96.

6. Stang PE, Vonkorff M. The diagnosis of headache in primary care: factors in the agreement of clinical and standardised diagnoses. Headache 1994;34:138-142.

7. Lipton RB. Disability assessment as a basis for stratified care. Cephalalgia 1998;18(Suppl 22):40-46.

8. Stewart WF, Lipton RB. Migraine headache; epidemiology and health care utilization. Cephalalgia 1993;13(Suppl 12):41-46. 